DOI: https://doi.org/10.24127/ajpm.v10i4.4361

\title{
VISUAL AND SYMBOLIC REPRESENTATION FORMING: A CASE OF RELATIONAL UNDERSTANDING ON ELEMENTARY STUDENT
}

\author{
Mohammad Faizal Amir ${ }^{1 *}$, Mahardika Darmawan Kusuma Wardana ${ }^{2}$, \\ Devi Usfuriah $^{3}$ \\ ${ }^{1 *}$ Universitas Muhammadiyah Sidoarjo, Indonesia \\ *Corresponding author \\ E-mail: $\quad$ faizal.amir@umsida.ac.id ${ }^{1 *}$ \\ mahardikadarmawan@umsida.ac.id ${ }^{2}$ \\ deviusfuriah@gmail.com $^{3 \text { ) }}$
}

Received 29 October 2021; Received in revised form 04 December 2021; Accepted 28 December 2021

\begin{abstract}
Abstrak
Penelitian ini bertujuan untuk menginvestigasi proses pembentukan representasi visual dan simbolik Anna pada setiap tahap perkembangan pemahaman relasional dalam menyelesaikan soal pecahan. Penelitian ini berfokus pada Anna (nama samaran), siswa kelas 4 SD dari suatu sekolah di Kabupaten Sidoarjo. Anna memiliki proses pembentukan representasi visual dan simbolik terlengkap dan merupakan satu-satunya siswa yang mampu memberikan argument logis untuk mendukung jawabannya. Penelitian ini merupakan penelitian kualitatif dengan studi kasus. Hasil penelitian dianalisis menggunakan model Miles dan Huberman dengan cara mereduksi data, menyajikan data, dan menarik kesimpulan. Hasil penelitian menunjukkan proses pembentukan representasi visual dan simbolik Anna pada setiap tahap perkembangan pemahaman relasional dalam menyelesaikan tugas soal pecahan. Anna kesulitan membentuk representasi visual karena memiliki kelemahan dalam konsep persamaan pecahan dan operasi pecahan. Hal ini mengakibatkan proses pembentukan representasi simbolik dan pengetahuan prosedural yang cenderung hafalan. Temuan ini menunjukkan bahwa Anna mengembangkan pemahaman relasional, yaitu pemahaman konseptual tentang pecahan. Proses pembentukan representasi visual merupakan dasar utama sebelum terbentuknya representasi simbolik.
\end{abstract}

Kata kunci: Pecahan; pemahamanrelasional; representasi

\begin{abstract}
This study investigates the process of forming Anna's visual and symbolic representations at each stage of the development of relational understanding in solving fractional problems. This study focuses on Anna (pseudonym), a 4th-grade elementary school student in Sidoarjo Regency. Anna possessed the complete process of forming visual and symbolic representations and is the only student who is able to provide logical arguments to support her answer. This research is qualitative in nature with a case study. The results were analyzed using the Miles and Huberman model by reducing the data, presenting the data, and drawing conclusions. Results show the process of forming Anna's visual and symbolic representations at each stage of the development of relational understanding in solving fractional problems. Anna has difficulty forming visual representations because she has weaknesses in the concept of fractional equations and fractional operations. This resulted in the process of forming symbolic representations and procedural knowledge that tends to be rote. These findings indicate that Anna developed a relational understanding, namely, a conceptual understanding of fractions. The process of forming a visual representation is the main basis before the formation of a symbolic representation.
\end{abstract}

Keywords: fraction; relational understanding; representation 
DOI: https://doi.org/10.24127/ajpm.v10i4.4361

\section{INTRODUCTION}

Many elementary school students have difficulty understanding fraction material (Hunt, Welch-ptak \& Silva, 2016). Difficulties experienced by students, especially in terms of adding different types of fractions, is due to students not having an understanding of the fractions equality and experiencing misconceptions about the comparison of the shape and size of the whole fraction (Jannah \& Prahmana, 2019; Loong, 2014; Ramadianti, Priatna \& Kusnandi 2019). Another difficulty is the students' failure to represent numerators and denominators visually (Namkung \& Fuchs, 2019). The students' understanding of fractions emphasized relational thinking about the numerator and denominator as determinants of the fraction value of the whole (Fuchs et al., 2017). This understanding relates to the students' experiences in converting fraction values into symbolic or visual representations. For example, the meanings 2 and 3 are written in the form of fractions into $\frac{2}{3}$ or describe them visually with area models (Fitzallen, 2015).

The students' difficulties in understanding fractions occur because of fundamental problems forming visual to symbolic representations (Nicolaou \& Pitta-Pantazi, 2016). The visual representation can increase credibility when solving and understanding a problem, especially in the field of mathematics, as well as make the students' understanding and reasoning better. Visual representation is widely used in teaching numerical and fraction material (Debrenti, 2015; Kashefi, Alias, Kahar, Buhari \& Zakaria, 2015; Özsoy, 2018) and a visual model that supports the teaching of mathematics about the problem of fractions (Mazzocco, Myers, Lewis, Hanich \&
Murphy, 2013). By contrast, symbolic representations are essential in a series of calculations using symbols when solving mathematical problems (Anwar \& Rahmawati, 2017). In addition, symbolic representations can relate knowledge about meaningful fractions by identifying multiplicative structures and proportional thinking (Ahl, 2016).

Understanding is a fundamental aspect to achieve other higher mathematical abilities (Nuraeni \& Luritawaty, 2017). There are two types of understanding that are often known: instrumental and relational understanding. Students who have a relational understanding can know the rules with a reason, while students who have an instrumental understanding know only the rules without any reason (Skemp, 2013). The development of the students' relational understanding is overly complex and is not limited to making connections between ideasconcepts learned, in which the development of the students' relational understanding takes a very long time. This will be very beneficial for students in the long run and may help students be motivated in learning mathematics (Baki, 2014; Anwar, Ipung, Abdur, Sisworo \& Dwi, 2016).

Previous studies on visual and symbolic representations in solving fractions related to the students' relational understanding have been conducted before. Manipulating fractional forms (either visually to symbolic or vice versa) intensively leads to the formation of relational understanding (Peppers, 2016). As a teaching model, visual representation provides changes and deepens the students' understanding of the analysis of fractional operations symbolically (Barbosa \& Vale, 2021). The elementary school students' 
understanding of contextual problems that are represented visually will form an abstraction of fractional division symbolically (Widada et al., 2020). The construction of elementary school students' schemas representing images (visuals) to symbols reflected the students' understanding of fraction solutions (Kurniawan, Sutawidjaja, As'Ari \& Muksar, 2018).

Based on previous studies, two research gaps were found. First, no literature on visual and symbolic representations on specifically developing a relational understanding of fractional problems has emerged. Second, there is still a lack of research on the formation of visual and symbolic representations in each development of relational understanding at the elementary school level. By contrast, student involvement that focuses on evaluating the formation of fractional value representations will provide general information on student competencies and the overall intervention conducted by teachers in learning, thus leading to an increase in the students' understanding in solving fraction problems (Fuchs et al., 2017; Tian \& Siegler, 2016). Thus, to overcome this gap, the purpose of this study was to analyze the process of forming visual and symbolic representations of elementary school students on each development of the students' relational understanding in solving fraction problems.

\section{THE RESEARCH METHODS}

Researchers used qualitative research with a case study method. Case studies are a method of inquiry to explore in-depth programs, events, activities, and processes for one or more individuals (Creswell, 2012). The case in this research is the phenomenon of students who have the ability to understand relational and good representation in solving problems in learning mathematics.

\section{Study Subjects}

This research involved 25 fourthgrade elementary school students in Sidoarjo, East Java, Indonesia, who are aged 9-10 years. To obtain students who have a good relational understanding and representation, the researcher divides students into three categories: students who do not have a relational understanding and representations are lacking, students who have sufficient relational understanding and representations, and students who have relational understanding and representations. Because students have obtained fractional material in class, researchers think that they can show a deep visual and symbolic representation in the fractional material.

In this research, the researcher focuses on only one student who has a good relational understanding and representation. This is intended to obtain in-depth information on the formation of visual and symbolic representation of students in each development of relational understanding. Based on the preliminary research, the researcher obtained Anna (pseudonym) as the research subject. Anna was chosen as the subject because she could make the most appropriate visual and symbolic representation on the preliminary problem of fractions and was the only student to provide rational arguments to support the answer.

\section{Instrument}

The instrument in this research is in the form of a Task of Fractions Representation (TFR) that has been 
DOI: https://doi.org/10.24127/ajpm.v10i4.4361

through a validation process by experts in the form of validation, content, and construct. TFR was tested on fourthgrade students in different schools. Results show that TFR can be used as a reference to find out visual and symbolic representations at each stage of the development of the students' relational understanding.

The TFR comprises three items. TFR is a task to present certain representations based on differences in values and the flat figures given and in terms of comparing fractional values. The TFR solution allows the use of three fraction models, namely, the whole or part-to-whole model, the use of fractions to show a portion of the whole, the fraction quotient model or fraction quotient, which is the division of one number with another, and the ratio model to compare one with another (Musser, Burger \& Peterson, 2011).

In TFR 1, the figure is flat, while the representation made by Anna must be rectangular. In TFR 2 , in addition to being asked to make another circle representation, this was intended to provide Anna some flexibility in making a form of representation (Table 1). In TFR 3, contextual tasks are intended to relate the mental processes formed when fractions are related to their daily experiences.

Tabel 1. The Task of Fractions Representation

\begin{tabular}{l} 
No. \\
\hline 1 If the rectangular figure below states $\frac{1}{2}$ \\
a. How about a rectangular figure that states $\frac{2}{2}, \frac{3}{2}, \frac{5}{2}$, and $\frac{3}{4}$ \\
b. By using a rectangular shape, which is greater between $\frac{5}{2}$ and $\frac{3}{4}$
\end{tabular}

2 If the circle figure below states $\frac{3}{4}$

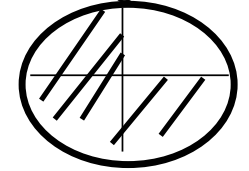

a. How about a circle figure that states $\frac{6}{4}$ and $\frac{4}{3}$

b. Can you make another two-dimensional figure (other than circle) that states $\frac{8}{5}$.

c. By stateing, compare which is greater between $\frac{6}{4}$ and $\frac{8}{5}$

3 If bread is currently worth $\frac{\mathbf{5}}{\mathbf{4}}$, then eaten $\frac{2}{3}$, what is the shape of the bread now? What is the size?

\section{Interview}

The interview used in this research is a structured interview (Creswell, 2012). The researcher interviewed Anna in accordance with the results of the answers to the TFR. During the process, the researcher recorded the interview and Anna's activities. This was done so that no information was left behind while forming Anna's representation 
DOI: https://doi.org/10.24127/ajpm.v10i4.4361

during the information-gathering process.

\section{Data analysis}

An analysis of the data used in the Miles and Huberman model was conducted based on TFR data and interactive interviews about the process of forming representation. The Miles and Huberman model analysis is divided into three, namely; 1) data reduction, namely, transcribing the results of Anna's answers, analyzing deeper into Anna's visual and symbolic representations, then selecting relevant data and grouping them; 2) Presentation of data, namely, exposure of the relationship between the process of forming visual representations and symbolic Anna based on the development of relational understanding, and 3) concluding, namely, the conclusion of the visual or symbolic representation of Anna on the fractional material in each development of relational understanding (Miles, Huberman \& Saldana, 2014).

In this research, Anna's visual and symbolic representation are categorized based on six stages in the development of relational understanding (Keene, Glass \& Kim, 2011), namely; 1) Students can anticipate the results of the implementation of the procedure without actually having to do it and they can anticipate the relationship of the expected results with the results of other procedures; 2) Students can identify when it is appropriate to use certain procedures; 3) Students can correctly conduct all procedures or steps selected in the procedure; 4) Students understand the reasons why a procedure works as a whole; 5) Students can symbolically or graphically verify the truth or reasonableness of the results recognized for the procedure without repeating the procedure; 6) Students can make relations within and across representations. In this research, these stages are used to identify the process of forming students' visual and symbolic representations to develop a relational understanding of fraction problems.

\section{Data legality}

The researcher uses technical triangulation by comparing the results of Anna's written task with interviews and documentation based on indicators of forming visual and symbolic representations in the development of relational understanding. This is done wherein the data on forming the representation obtained has conformity during the data collection process.

\section{RESULTS AND DISCUSSION}

In this section, Anna's work on TFR and the interview footage are presented to determine the process of forming visual and symbolic representations in detail.

\section{The result on TFR 1}

Anna's work on TFR 1 shows the formation of visual and symbolic representations (see Figure 1). 
DOI: https://doi.org/10.24127/ajpm.v10i4.4361

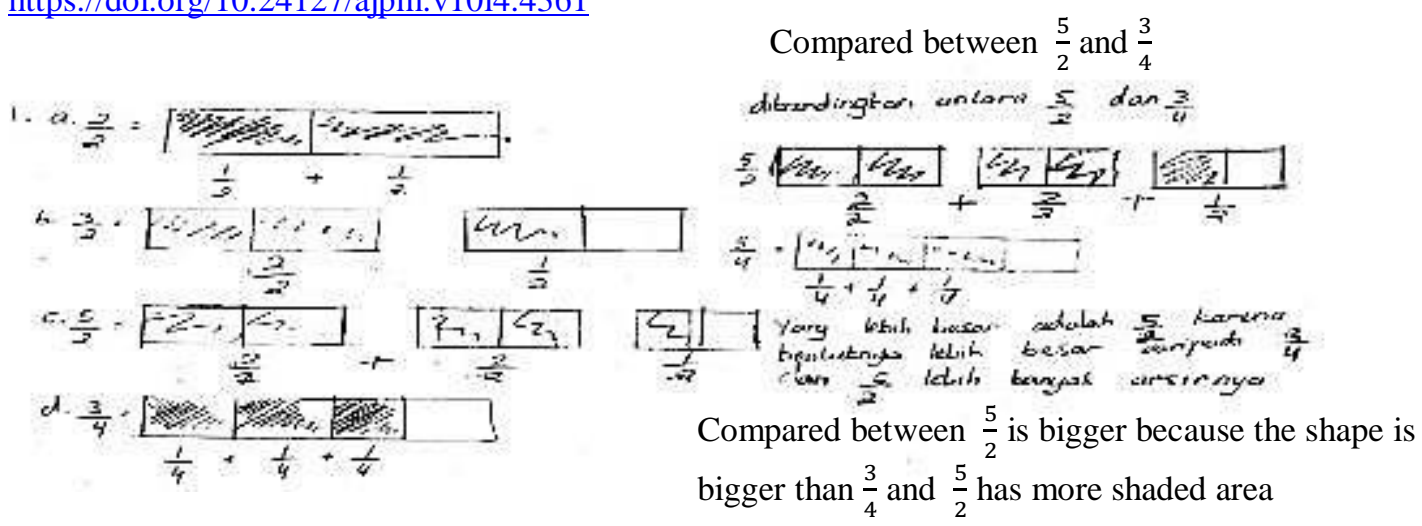

Figure 1. Anna's answer on TFR 1

In Figure 1, Anna can guess the shape and size of the rectangular image that states $\frac{2}{2}, \frac{3}{2}, \frac{5}{2}$, and $\frac{3}{4}$ by looking at the rectangle shape that states $\frac{1}{2}$. When interviewed, Anna can explain the contents of the task, wherein she can anticipate the results by guessing and relating to TFR 1 .

Anna can identify the procedure used by first understanding the task content, in which she can determine the procedure that is represented visually and symbolically. By identifying the procedure used by Anna to multiply rectangles that represent $\frac{1}{2}$ and add up fractions $\frac{1}{2}, \frac{2}{2}$, and $\frac{1}{4}$ to find out rectangles that state $\frac{2}{2}, \frac{3}{2}, \frac{5}{2}$, and $\frac{3}{4}$ according to the number of numerators asked in TFR 1. When interviewed, Anna was able to explain the procedure used, but she was more focused on explaining the procedure represented in the visual form of a rectangular image, the number of rectangles that stated $\frac{1}{2}$ to answer TFR 1.

Anna can use the entire procedure used by representing it in visual and symbolic form. Anna uses a procedure by describing and adding rectangles that state $\frac{1}{2}, \frac{2}{2}$, and $\frac{1}{4}$. This is done to determine the shape and size of the rectangle that states $\frac{2}{2}, \frac{3}{2}, \frac{5}{2}$, and $\frac{3}{4}$. When interviewed, Anna can explain the procedures used in working on TFR 1 .

Anna is able to understand the procedures used in both procedures that are represented in visual and symbolic forms. Anna can understand the shape of the rectangle and the size of the rectangle by relating a rectangle that represents the fraction $\frac{1}{2}$, but when interviewed, Anna was unable to explain the reasons for using the procedure in detail. Anna only replied that the reason was easier and faster to understand.

Anna did not verify the truth or reasonableness of the results that have been achieved, wherein the figure Anna made did not match the shape of the rectangle figure that stated $\frac{1}{2}$ and the rectangular shape that stated $\frac{3}{4}$ the size did not match the shape of the complete rectangle. When interviewed, Anna was convinced of the results of the answers and procedures used without checking again.

Anna is able to make connections and the results of her connections are written in the form of symbols and visuals. Anna described a rectangular shape that states $\frac{5}{2}$ and $\frac{3}{4}$ and compared various shapes with larger and smaller 
denominators. When interviewed, Anna was also able to make a connection by comparing the shape and size of the image that states fractions in the form of visual, symbolic, and written representations.

\section{The result on TFR 2}

Anna's work on TFR 2 showed the formation of visual and symbolic representations (see Figure 2).

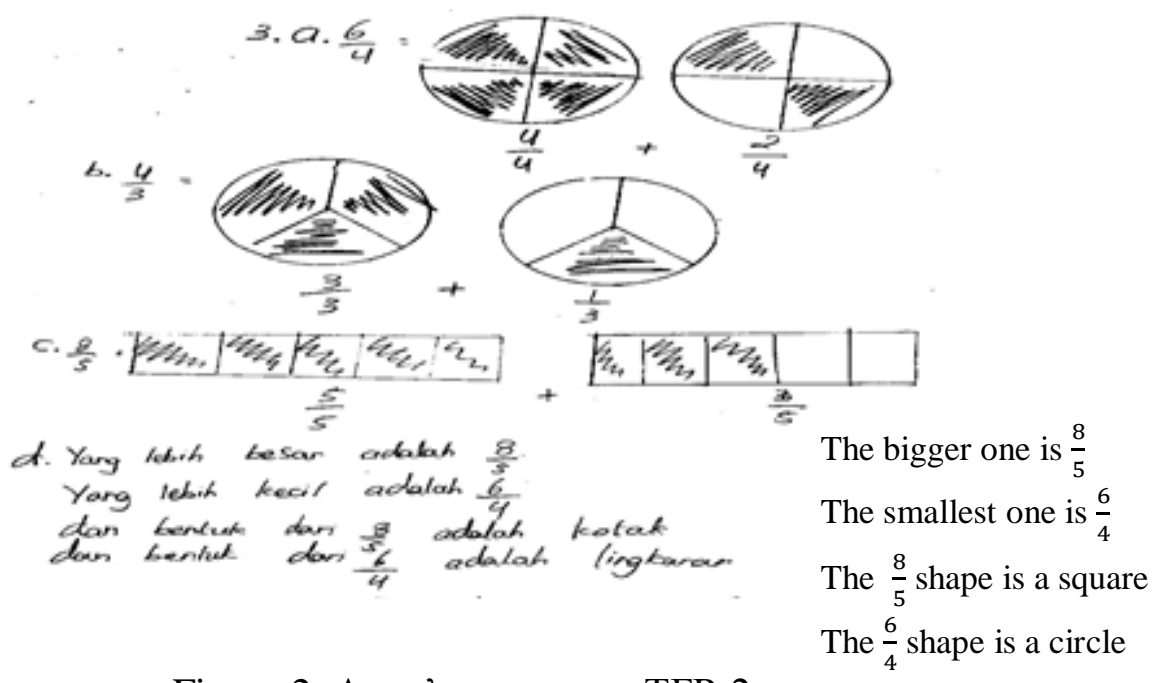

Figure 2. Anna's answer on TFR 2

In Figure 2, the piece shows that Anna could guess the results represented in visual and symbolic forms. Anna guessed the results of the circle and rectangle shape by looking at TFR 2 and adding up the fraction size, wherein it formed a circle that stated $\frac{6}{4}$ and $\frac{4}{3}$ and a rectangular shape that stated $\frac{8}{5}$. When interviewed, Anna can guess the essence of the questions in the questions and the results of the shapes of circles and rectangles that state $\frac{6}{4}, \frac{4}{3}$, and $\frac{8}{5}$, which can be connected to the images on TFR 2.

Anna is able to identify procedures represented visually and symbolically. Anna identified the procedure used to find out the shape of a circle states $\frac{6}{4}$ by drawing two circle shapes divided into four parts after connecting with the figure on TFR 2. The procedure used by Anna to find out the shape of a circle states $\frac{4}{3}$ by drawing two shapes circle is divided into three parts. The procedure used to determine the shape of a rectangle that states $\frac{8}{5}$ by drawing two rectangular shapes were divided into five parts. When interviewed, Anna was able to identify the procedure after knowing the essence of the question in TFR 2.

Anna was able to use the whole procedure represented in visual and symbolic forms. Anna used the procedure to determine the shape and size of fractions that stated $\frac{6}{4}$ by drawing two circle shapes divided into four parts in all shaded and shaded two parts. Anna added $\frac{4}{4}$ fractions to $\frac{2}{4}$ fractions. Anna used the procedure to determine the shape and size of fractions that stated $\frac{4}{3}$ by drawing two circle shapes divided into three parts in all shaded and shaded 1 part and Anna added $\frac{3}{3}$ 
DOI: https://doi.org/10.24127/ajpm.v10i4.4361

fractions to $\frac{1}{3}$ fractions. Anna used the procedure to find out the shape and size of fractions that stated $\frac{8}{5}$ by drawing two rectangular shapes divided into five parts in all shaded and shaded three parts and Anna added $\frac{5}{5}$ fractions to $\frac{3}{5}$ fractions.

Anna understands the procedures that are used visually and symbolically. She is able to draw correctly according to the size of the fraction determined by the circle shape and the rectangular shape by connecting the known image to TFR 2. Anna can add up the size of the circle shape that states $\frac{6}{4}$ and $\frac{4}{3}$ and is able to understand the sum of the shape sizes other than the circle that states $\frac{8}{5}$ correctly. When interviewed, Anna was able to explain the procedure used, but in explaining the reasons for using the procedure, she was less specific, wherein the answers she gave were less understood during the question and answer process.

Anna did not verify the answers' results even though her answer was correct and appropriate. The procedure used by Anna was correct, but the circle shape was made smaller than the circle contained in TFR 2. When interviewed, she was sure of the results of the answers and procedures used, but she did not verify it again and only skimmed it.

Anna is able to make connections that are represented in visual and symbolic form by describing and comparing the same shape and different shapes of fractions $\frac{5}{4}, \frac{6}{5}$, and $\frac{5}{6}$ by making a relationship from the shape of the image to the size of the fraction that represents the image. Anna can provide reasons in verbal and symbolic form. When interviewed, she was able to explain the results of the work done, but she did not explain it all. Thus, her answer was more incomplete than what was asked. Anna can conclude by comparing the size of flat shapes with different shapes and mentioning the reasons well.

\section{The result on TFR 3}

Anna's work on TFR 3 shows the formation of visual and symbolic representations (see Figure 3)

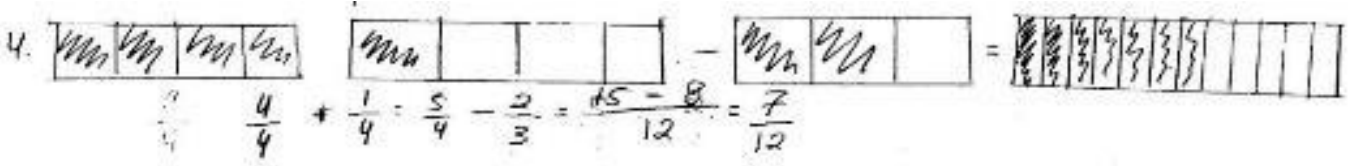

Figure 3. Anna's answer on TFR 3

In Figure 3, Anna can guess the shape of the bread by describing the shape of the bread, which states the fractions of $\frac{5}{4}$ and $\frac{2}{3}$ in the form of a rectangle, and she can describe the results in the form of a rectangle, which states $\frac{7}{12}$ which is the result of the shape of the bread after eating. Anna also performed a $\frac{5}{4}$ fracture reduction operation with $\frac{2}{3}$ fractions, in which she could determine the size of the bread in question. When Anna was interviewed, she could also guess the gist of what was asked by reading TFR 3 .

Anna was able to identify the procedure represented visually and symbolically. Anna identifies the procedure precisely and sequentially by drawing a bread in a rectangular shape that states the fraction of $\frac{5}{4}$ by making two rectangular shapes divided into four parts and drawing bread in a rectangular 
shape, stating $\frac{2}{3}$ by making one rectangular shape that is divided into three parts. Anna also conducted a cheating operation by matching the denominator to determine the results of the current size of the bread. When interviewed, she can mention the procedures used sequentially to determine the results of what was asked on TFR 3.

Anna is able to use procedures that are represented in visual and symbolic forms. The procedure used by Anna to determine the shape of the bread states the fraction of $\frac{5}{4}$ by describing two rectangular shapes divided into four parts, then shaded all and shaded one part. The procedure used by Anna to find out the shape of the bread states $\frac{2}{3}$ fractions by describing one rectangular shape, which is divided into three parts then shaded in two, in which the remaining one part. Anna illustrates the results of the present bread shape by depicting one rectangular shape divided into 12 parts, then shading seven. Thus it can state $\frac{7}{12}$. Anna conducted a rigging operation on the fraction of $\frac{5}{4}$ minus $\frac{2}{3}$, which was first equated by the denominator and it can be found that the denominator is 12 , in which it obtained $\frac{15}{12}$ minus $\frac{8}{12}$ and the result can be found, which is $\frac{7}{12}$. When interviewed, Anna can use the procedure used, but Anna cannot explain it in detail only answering can.

Anna is able to understand the procedures used visually and symbolically. Anna was able to draw a bread stating the fractions $\frac{5}{4}$ and $\frac{2}{3}$ and the results of reducing the fractions $\frac{5}{4}$ and $\frac{2}{3}$ in a rectangular shape correctly and precisely. Although the denominator is different, Anna observes the size of the image made. Anna understands the fraud operation by equating the denominator first to determine the results. When interviewed, Anna can explain why using fraud operations and equating the denominator in answering questions in detail and with their reasons.

Anna does not verify the results of the answers made, but she pays attention to the instructions in TFR 3, in which she can draw correctly and accordingly. Anna in describing it is not quite right when seen from the shape of the rectangle drawn and the way Anna divides the rectangular shape, which states that the fractions $\frac{5}{4}$ and $\frac{2}{3}$ are not the same shape, and the shape of the bread still has the wrong shape. The results of Anna's cheating operation paid attention to the different denominators, wherein the results are correct and correct as asked. When interviewed, Anna only skimmed, and she also did not verify the use of fraud operations.

Anna is able to make connections that are represented in visual and symbolic forms. Anna can describe the bread in a rectangular shape by conducting a deduction operation, where the denominator has been equated in advance, and the visual representation that Anna makes with the symbolic representation is interconnected, and the results are the same even though they represented it differently. When interviewed, Anna was also able to connect by describing the present and after-eaten form of the bread compared to conducting a cheating operation on the problem, in which the final result of the answer could be either symbolic or visual.

Based on the results of the formation of representation in the 
development of relational understanding on all TFR, important points have emerged. In TFR 1, Anna can understand the fraction problem by describing it as a rectangle. Anna can solve problems from beginning to end by visually representing them by drawing a rectangle according to the numerator and the denominator. However, Anna's visual representation is not the same size as the image on TFR 1, while the size is smaller than a complete rectangle, in which Anna's figure is inaccurate, but she can make the final result of different fraction sizes. This is consistent with the opinion of previous research that inaccurate representation for reasons of certain errors can affect the results of the subject's representation (Anwar et al., 2016).

The opinion of the previous research also states that inaccurate visual representation reduces the chances of students to solve problems, which need to be considered successful is reading comprehension related to solving word problems in item weights (Boonen, Van Wesel, Jolles \& Van der Schoot, 2014). Anna can draw according to the number of numerators and denominators, but the rectangular shape described by Anna is not the same size because Anna, in dividing it is not the same size. According to previous research, students can model fractions in drawings according to their numerator and denominator. However, students do not divide the same parts due to their lack of drawing ability and do not understand that fractions must be divided into equal parts in complex fractions (Aksoy \& Yazlik, 2017).

In TFR 2, Anna can understand the procedure used and Anna can draw a circle and rectangle, but students are more easily represented in a circle while working on the problems. This is consistent with the previous research findings that students work better with circle representations than rectangular representations or number lines (TunçPekkan, 2015). The figure Anna made was in accordance with what was asked about the problem, only the figure of the fractional size that the students drew was smaller than the circle given to the problem, but the rest Anna could understand the contents of the problem. The representation of fractions depicted in the form of rectangles and circles can be connected and the shape of the circle is more easily understood because it is in harmony with the empirical costume of the students' understanding of partial and whole fractions (Boyce \& Moss, 2017). Anna can compare the shapes of circles and rectangles and draw them according to the numerator and denominator of the fraction. Students can compare shapes of circles and rectangles and draw them according to numerators and denominators in fractions (Tunç-Pekkan, 2015).

In TFR 3, Anna has worked on story problems well and represented them in visual or symbolic forms, but when students represented them in visual form, it is difficult to describe the shape of bread before, wherein bread that is eaten and bread after being eaten, but the size made by students is not accurate where after the edible bread size becomes larger than the bread before eating and in describing the shape of fractions do not pay attention to the symbolic representation, wherein the images and symbols that are represented do not correspond to the shape of bread.

The formation of visual representations can build new knowledge to improve learning outcomes (Johnson, Butcher, Ozogul\& 
Reisslein, 2013). Visual representations can be seen as cognitive tools to facilitate learning from concrete to abstract contexts (Gebre, 2018). This representation provides important information about the process of forming formal solutions (Gagatsis \& Elia, 2004). In problem-solving, visual representation forms can be expressed in images, diagrams, or graphs (Jitendra \& Woodward, 2019). Visual representations often made it easier to solve geometry and fraction problems (Mazzocco et al., 2013).

While the process of forming the students' symbolic representations is seen when using symbols in the calculation process to obtain symbolic values when solving problems by identifying problems in the form of symbols as variables whose values are unknown (Anwar \& Rahmawati, 2017). In symbolic representations, the students' problems are expressed in terms of numbers, algebraic symbols, operations, and relationship signs (Ott, Brünken, Vogel \& Malone, 2018). Symbolic representations are mathematical representations and graphs in numbers (Becker et al., 2015).

Elementary school students have difficulty representing fractions visually by modeling the concept of denominators and numerators of fractions, ranking fractions, differentiating fractions, and operating fractions to avoid misunderstanding (Deringöl, 2019). Although the accuracy of the representation of fractions is important, students have a conceptual understanding of fractions and arithmetic fractions (Siegler et al., 2013). However, use visual representations that cause great difficulties in most mathematical tasks, and mathematical problems are not only types of computational tasks, but they also require the selection of strategies and appropriate decisions that lead to logical solutions (Ahmad, Tarmizi \& Nawawi, 2010; Cartwright, 2020). Word problem-solving is one important component of mathematical problemsolving that combines real-life problems and applications. According to previous research, many students experience mistakes caused by students obtaining traditional learning; therefore, learning is indicated to make a visual representation of real-world situations to clarify problems and facilitate their resolution (Sari, Darhim, \& Rosjanuardi, 2018). In addition, their limited faction knowledge will disrupt the transfer of knowledge from the visual fraction model to a symbolic (number-based) representation (Mazzocco et al., 2013).

\section{CONCLUSION AND SUGGESTION}

Based on the research results, Anna can conduct the process of forming visual and symbolic representations at each stage of developing a relational understanding of fraction problems. The process comprises (1) anticipating the results of implementing the procedure without actually having to do it and anticipating the relationship of the expected results with the results of other procedures. Generally, this is conducted by identifying problems and linking them to other problem procedures. (2) Identifying the right time to use certain procedures. (3) Conducting all procedures or steps chosen in the procedure. (4) Understanding the reasons why a procedure works as a whole. (5) Symbolically or graphically verifying the truth or fairness of the results recognized for the procedure without repeating the procedure. (6) Making connections within and across representations. In some tasks, Anna 
has difficulty in representing fractions visually. This affects memorizing symbolic and procedural knowledge that is memorized. Researchers argued that this is because Anna is accustomed to receiving traditional learning. She only knows one completion procedure and has difficulty representing fractions of various known forms of representation.

Researchers indicated that students have a good development of relational understanding in learning fractional material. The teacher must embed the concepts of fraction equality and fraction operations with various forms of representation. However, the presentation of visual representations became the main basis before it led to the presentation of symbolic representations. This is done to make students understand the value of the numerator and denominator of fractions. In addition, teachers must be accustomed to presenting different tasks through variations in representation. With regard to further research, the results of this research can be followed up for more than one student. Aside from the process of forming representation in every relational understanding development, it would be interesting if it is seen in students who tend to lack the understanding of the problem of fractions, which are students who have the category of instrumental understanding.

\section{REFERENCES}

Ahl, L. M. (2016). Research findings' impact on the representation of proportional reasoning in swedish mathematics textbooks. Journal of Research in Mathematics Education, 5(2), 180-204. https://doi.org/10.4471/redimat.20 16.1987
Ahmad, A., Tarmizi, R. A., \& Nawawi, M. (2010). Visual representations in mathematical word problem solving among form four students in malacca. Procedia - Social and Behavioral Sciences, 8(5), 356361.

https://doi.org/10.1016/j.sbspro.20 10.12.050

Aksoy, N. C., \& Yazlik, D. O. (2017). Student errors in fractions and possible causes of these errors. Journal of Education and Training Studies, $\quad 5(11), \quad 219$. https://doi.org/10.11114/jets.v5i11. 2679

Anwar, R. B., Ipung, Y., Abdur, R. A., Sisworo, \& Dwi, R. (2016). Mathematical representation by students in building relational understanding on concepts of area and perimeter of rectangle. Educational Research and Reviews, 11(21), 2002-2008. https://doi.org/10.5897/err2016.28 13

Anwar, R. B., \& Rahmawati, D. (2017). Symbolic and verbal representation process of student in solving mathematics problem based polya's stages. International Education Studies, 10(10), 20. https://doi.org/10.5539/ies.v10n10 p20

Baki, A. (2014). Kuramdan uygulamaya matematik eğitimi (in english mathematics education from theory to practice). Harf Eğitim Publishing.

Barbosa, A., \& Vale, I. (2021). A visual approach for solving problems with fractions. Education Sciences, 11(11), $1-18$. https://doi.org/10.3390/educsci111 10727

Becker, N., Stanford, C., Towns, M., \& Cole, R. (2015). Translating across 
macroscopic, submicroscopic, and symbolic levels: the role of instructor facilitation in an inquiryoriented physical chemistry class. Chemistry Education Research and Practice.

https://doi.org/10.1039/C5RP0006 $4 \mathrm{E}$

Boonen, A. J. H., Van Wesel, F., Jolles, J., \& Van der Schoot, M. (2014). The role of visual representation type, spatial ability, and reading comprehension in word problem solving: An item-level analysis in elementary school children. International Journal of Educational Research, 68, 15-26. https://doi.org/10.1016/j.ijer.2014. 08.001

Boyce, S., \& Moss, D. (2017). Role of representation in prospective teachers' fractions schemes. North American Chapter of the International Group for the Psychology of Mathematics Education, 829-836.

Cartwright, K. (2020). Analyzing students' communication and representation of mathematical fluency during group tasks. Journal of Mathematical Behavior, 60(October), 100821. https://doi.org/10.1016/j.jmathb.20 20.100821

Creswell, J. W. (2012). Educational research: Planning, conducting, and evaluating quantitative and qualitative research. Pearson Education.

Debrenti, E. (2015). Visual Representations In Mathematics Teaching: An Experiment With Students. Acta Didactica Napocensia, 8(1), 21-26.

Deringöl, Y. (2019). Misconceptions of primary school students about the subject of fractions: Views of primary teachers and primary preservice teachers. International Journal of Evaluation and Research in Education (IJERE), 8(1), 29. https://doi.org/10.11591/ijere.v8i1. 16290

Fitzallen, N. (2015). When does $1 / 2=$ 1/3?: Modelling with wet fractions. Australian Mathematics Teacher, 71(1), 36-40. https://eric.ed.gov/?id=EJ1093094

Fuchs, L. S., Malone, A. S., Schumacher, R. F., Namkung, J., \& Wang, A. (2017). Fraction intervention for students with mathematics difficulties: Lessons learned from five randomized controlled trials. Journal of Learning Disabilities, 50(6), 631639.

https://doi.org/10.1177/002221941 6677249

Gagatsis, A., \& Elia, I. (2004). The effects of different modes of representation on mathematical problem solving. Proceedings of the 28th Conference of the International Group for the Psychology of Mathematics Education, 2, 447-454. https://eric.ed.gov/?id=ED489751

Gebre, E. (2018). Learning with multiple representations: Infographics as cognitive tools for authentic learning in science literacy. Canadian Journal of Learning and Technology, 44(1), $1-24$.

https://doi.org/http://dx.doi.org/10. 21432/cjlt27572

Hunt, J. H., Welch-ptak, J. J., \& Silva, J. M. (2016). Initial understandings of fraction concepts evidenced by students with mathematics learning disabilities and difficulties: A framework. Learning Disability 
DOI: https://doi.org/10.24127/ajpm.v10i4.4361

Quarterly, 39(4), 213-225. https://doi.org/10.1177/073194871 6653101

Jannah, A. F., \& Prahmana, R. C. I. (2019). Learning fraction using the context of pipettes for seventhgrade deaf-mute student. Journal for the Education of Gifted Young Scientists, 7(2), 299-321. https://doi.org/10.17478/jegys.576 234

Jitendra, A. K., \& Woodward, J. (2019). The role of visual representations in mathematical word problems. In Cognitive Foundations for Improving Mathematical Learning (1st ed., Vol. 5). Elsevier Inc. https://doi.org/10.1016/b978-0-12815952-1.00011-6

Johnson, A. M., Butcher, K. R., Ozogul, G., \& Reisslein, M. (2013). Learning from abstract and contextualized representations: The effect of verbal guidance. Computers in Human Behavior, 29(6), 2239-2247. https://doi.org/10.1016/j.chb.2013. 05.002

Kashefi, H., Alias, N. A., Kahar, M. F., Buhari, O., \& Zakaria, S. (2015). Visualisation in mathematics problem solving. E-Proceeding of the International Conference on Social Science Research, 576-585.

Keene, K. A., Glass, M., \& Kim, J. H. (2011). Identifying and assessing relational understanding in ordinary differential equations. Proceedings - Frontiers in Education Conference, FIE, July 2015.

https://doi.org/10.1109/FIE.2011.6 143074

Kurniawan, H., Sutawidjaja, A., As'Ari, A. R., \& Muksar, M. (2018). The thinking process of students in representing images to symbols in fractions. Journal of Physics: Conference Series, 1028(1). https://doi.org/10.1088/17426596/1028/1/012138

Loong, E. Y. K. (2014). Fostering mathematical understanding through physical and virtual manipulatives. Australian Mathematics Teacher, 70(4), 3-10. Mazzocco, M. M. M., Myers, G. F., Lewis, K. E., Hanich, L. B., \& Murphy, M. M. (2013). Limited knowledge of fraction representations differentiates middle school students with mathematics learning disability (dyscalculia) versus low mathematics achievement. Journal of Experimental Child Psychology, 115(2), 371-387. https://doi.org/10.1016/j.jecp.2013. 01.005

Miles, M. B., Huberman, A. M., \& Saldana, J. (2014). Qualitative data analysis: A methods sourcebook (third edit). SAGE Publications, Inc.

Musser, G. L., Burger, W. F., \& Peterson, B. E. (2011). Mathematics for elementary teachers: A contemporary approach (Ninth). John Wiley \& Sons, Inc.

Namkung, J., \& Fuchs, L. (2019). Remediating difficulty with fractions for students with mathematics learning difficulties. Learning Disabilities: A Multidisciplinary Journal, 24(2), 36-48.

https://doi.org/10.18666/ldmj2019-v24-i2-9902

Nicolaou, A. A., \& Pitta-Pantazi, D. (2016). Hierarchical levels of abilities that constitute fraction understanding at elementary school. International Journal of 
DOI: https://doi.org/10.24127/ajpm.v10i4.4361

Science and Mathematics

Education, 14(4), 757-776. https://doi.org/10.1007/s10763-

014-9603-4

Nuraeni, R., \& Luritawaty, I. P. (2017).

Perbandingan kemampuan pemahaman matematis siswa antara yang menggunakan pembelajaran inside-outside-circle dengan konvensional. Jurnal "Mosharafa," 6(3), 441-450.

Ott, N., Brünken, R., Vogel, M., \& Malone, S. (2018). Multiple symbolic representations: The combination of formula and text supports problem solving in the mathematical field of propositional logic. Learning and Instruction, 58, 88-105. https://doi.org/10.1016/j.learninstr uc. 2018.04 .010

Özsoy, G. (2018). Pre-service teachers' use of visual representations. International Electronic Journal of Elementary Education, 11(1), 4954.

https://doi.org/10.26822/IEJEE.20 18143960

Peppers, D. S. (2016). An exploratory study of the impact of a manipulatives-intensive fractions unit during a middle grades methods course on prospective teachers' relational understanding of fractions. In Electronic Theses and Dissertations Auburn University.

http://hdl.handle.net/10415/5511

Ramadianti, W., Priatna, N., \& Kusnandi. (2019). Misconception analysis of junior high school student in interpreting fraction. Journal for the Education of Gifted Young Scientists, 7(4), 1159-1173. https://doi.org/10.17478/jegys.631 567

Sari, D. P., Darhim, D., \& Rosjanuardi,
R. (2018). Errors of students learning with react strategy in solving the problems of mathematical representation ability. Journal on Mathematics Education, 9(1), 121-128. https://doi.org/10.22342/jme.9.1.43 78.121-128

Siegler, R. S., Fazio, L. K., Bailey, D. H., \& Zhou, X. (2013). Fractions: The new frontier for theories of numerical development. Trends in Cognitive Sciences, 17(1), 13-19. https://doi.org/10.1016/j.tics.2012. 11.004

Skemp, R. R. (2013). Relational understanding and instrumental understanding. National Council of Teachers of Mathematics, 26(3), 9-15.

Tian, J., \& Siegler, R. S. (2016). Fractions learning in children with mathematics difficulties. Journal of Learning Disabilities, 50(6), 17.

https://doi.org/10.1177/002221941 6662032

Tunç-Pekkan, Z. (2015). An analysis of elementary school children's fractional knowledge depicted with circle, rectangle, and number line representations. Educational Studies in Mathematics, 89(3), 419-441.

https://doi.org/10.1007/s10649015-9606-2

Widada, W., Herawaty, D., Lusiana, D., Afriani, N. H., Sospolita, N., Jumri, R., \& Trinofita, B. (2020). How are the process of abstraction of the division of fraction numbers by elementary school students? Journal of Physics: Conference Series, 1657(1), 1-7. https://doi.org/10.1088/17426596/1657/1/012040 